\title{
The Effect of Organic Liquid Fertilizer Application on Fish Pond's Water Quality at the Reclaimed Indonesian Tidal Lowland
}

\author{
Mirna Fitrani $^{1}$, Marsi ${ }^{2}$, Robiyanto H Susanto ${ }^{2}$ and Santa Dewi ${ }^{1}$ \\ ${ }^{1}$ Aquaculture Study Program, Sriwijaya University, Palembang, Indonesia \\ Email: fitranimirna@gmail.com \\ ${ }^{2}$ Soil Science Dept., Faculty of Agriculture, Sriwijaya University, Palembang, Indonesia \\ Email: mbasihin1960@yahoo.com; robiyanto@lowlands-info.org
}

\begin{abstract}
Mirna Fitrani, Marsi, Robiyanto H, Susanto, and Santa Dewi. 2016. The Effect of Organic Liquid Fertilizer Application on Fish Pond's Water Quality at the Reclaimed Indonesian Tidal Lowland. Aquacultura Indonesiana. 17 (2): 75-79. Organic liquid fertilizer is the source of nutrients. This fertilizer can be used to improve the water quality. It is enviromentally friendly and relatively cheap. Application of the fertilizer has been done on aquaculture. At the tidal lowland areas, application of this fertilizer is mostly as soil improvement agent. It is limited to be used as water quality improvement agent. Tidal lowland has an acid soil with a low fertility level characters. The objectives of the study are to know the effect of liquid organic fertilizer to the water quality (temperature, $\mathrm{pH}$, dissolved oxigen, ammonia) and to the amount of plankton in the ponds. This research was done at the reclaimed tidal lowland in Banyuasin District of South Sumatera, Indonesia. The organic liquid fertilizer was made by fermentation of both animals manures and vegetable waste with the percentage of $\mathrm{N}: \mathrm{P}_{2} \mathrm{O}_{5}: \mathrm{K}_{2} \mathrm{O}$ were $0.120: 0.023: 0.750$. Water quality data was taken three times in every three days (plankton) from the ponds that was added by liquid fertilizer with dose of $4.35 \mathrm{~L} /$ pond (P1) and $8.7 \mathrm{~L} /$ pond (P2). All the water quality data were analyzed qualitatively. The results show that on treated ponds $\mathrm{pH}$ dropped slightly since the beginning with $\mathrm{pH} 6.0$ and remain $6.4-6.8$ in the last day. The value of Ammonia ranges $0.06-0.15 \mathrm{mg} / \mathrm{L}$ and Dissolve oxigen range $1.9-2.5 \mathrm{mg} / \mathrm{L}$. Phytoplankton and zooplankton amount increased and reached the peak on day 12 (12,033 ind/L and $364 \mathrm{ind} / \mathrm{L}$ respectively), and finally turned down slowly. Therefore, liquid fertilizer addition should be given to the ponds more than once during fish rearing period. It is in order to increase the amount of plankton and to manage the water quality in the reclaimed tidal lowlands ponds .
\end{abstract}

Keywords: Organic liquid fertilizer; Reclaimed tidal lowland; Water quality

\section{Introduction}

Reclaimed tidal lowland has been developed by the Indonesian Government to improve the people prosperity. During the early period of development, it is used for agriculture, plantation, forestry, industry and housing, while aquaculture was still depend on catching (Susanto, 2010). However, some farmers have started to utilize their house yard to rear the fish. According to Fitrani (2013), dig ponds in almost every farmer's house yard could be used to fish rearing. The weakness was the poor of water quality, so it could not support the fish survival and growth. Marsi et al. (2014) explained that the level of water acidity and pyrite content were high and impact the fish survival and growth percentage. One of solution that has done to solve the acidity in reclaimed tidal lowland pond was Leaching (Fitrani et al., 2014 and Suwanda et al., 2016). Those researchs show that the percentage of survival and growth of fish increased after leaching treatment. Leaching effecting water quality in the fish pond with tidal water mechanism. Tidal water provide the new water to change the fish water media as long as the culture taking place. Nevertheles, leaching method has a draw back, the water source which is used must has better quality than the water in the ponds. Therefore, it need to be fresh to be able to flush the water in the pond. The water quality in reclaimed tidal lowland area is effected by tidal and rain fall level. Generally when the rain fall level is high, the water quantity and wter level go up. Contrastly when the dry season come, the water level which will affect the water quality, specially acidity of the water.

Another solution to manage the water quality and improve ponds productivities are lime and fertilizer application. Generally, the fuction of liming is to improve $\mathrm{pH}$ (Boyd and Tucker, 2014) and fertilizer role is to increase the nutrients concentration and grow the algae (live feed) in the pond. Organic liquid fertilizer comes from both plant and animal waste composed that has some advantages, such as able to improve the land and water quality, and could be used as feed directly by fish. Beside that, it is cheaper than 
anorganic fertilizer (Sedana et al., 2004). The addition of organic fertilizer on the pond that has added lime is expected to manage the water quality, physically, chemically and biologically. It is in order to support the survival and growth of fish rearing in the pond.

\section{Materials and Methods}

The study was conducted since February until September 2016 at Tanjung Lago Village, Banyuasin District, South Sumatera, Indonesia. Water quality analysis was done in Balai Teknik Kesehatan Lingkungan and Pusat Data Informasi Daerah Rawa dan Pesisir laboratory, Palembang, South Sumatera.

\section{Liming and Organic Liquid Fertilizer}

This research used $1.5 \mathrm{~kg} / \mathrm{m}$ dolomit (Suriadikarta, 2005) and organic liquid fertilizer made by fermented both animal and vegetable waste with the percentage of $\mathrm{N}: \mathrm{P}_{2} \mathrm{O}_{5}: \mathrm{K}_{2} \mathrm{O}$ were $0.12: 0.0231: 0.75$. There were three ponds (each pond sized $33.25 \mathrm{~m}^{2}$ ) used with dose $4.35 \mathrm{~L}(\mathrm{P} 1)$, 8.7 L (P2) and without fertilizer (P0) as control.

\section{Water Sampling and Water Quality Analysis}

Water samples were taken in the canals and ponds and measured insitu for $\mathrm{pH}$, dissolved oxygen, and temperature, while ammonia was analysed at laboratory. Plankton samples were taken with the plankton net sized $25 \mu$ (Haryadi et al., 1992) and observed three times in every 3 days for 18 days. The identification of plankton was done by microscope based on Davis (1955), Mizuno (1979) and Edmondson (1959).

\section{Data Analysis}

The amount of Plankton was calculated based on American Public Health Association (APHA, 1989). All the water quality data were analysed descriptively, and presented in the form of tables and graphs.

\section{Results and Discussions}

Based on observation, water quality of some sources in tidal lowland such as primer, secunder, tertier canal were in poor condition. It is expected influenced by the season and tidal water condition. In the rainy season, tidal lowland water source will be quite good and able to support the fish rearing. Unfortunately when the dry season comes, the result shows that the water quality in the canals and pond were not good to rear fish (Table 1).

Water temperature on location ranged normal $\left(27-31^{\circ} \mathrm{C}\right)$ for aquaculture organism such fish. This is becaused the sampling was done before the wet dry season (still there was rain eventhough low intensity) on February-July (Figure 1). Yet, the changes of weather in previous year (2015) influenced the dry season longer in 2016 and gave bad effect to water quality condition especially at the reclaimed tidal lowland.

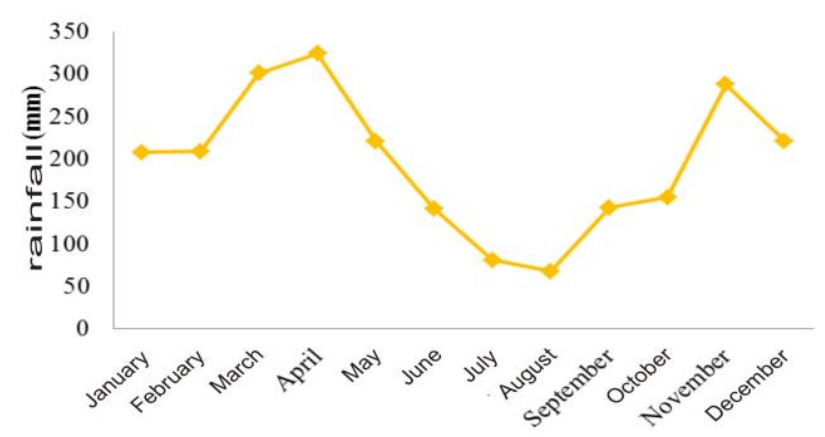

Source : Meteorology and Geophysics, Klimatologi Station Class II, Kenten Palembang

Figure 1. Estimated Rainfall level Data in 2016

In general, Table 1 shows that the water $\mathrm{pH}$ is very acid, eventhough there is also $\mathrm{pH}$ near netral ( $\mathrm{pH} \mathrm{6)}$. These is because in the dry season, water level in canals declined. In that condition the tidal lowland which has high pyrite content will be oxidized and produce suphate acid (Priatmadi and Haris (2009) that very dangerous for water ogranism. Table 1 also shows that the contain of dissolved oxigen in each canal was very low. This is expected that there was huge microorgasm activities. Based on Salam (2010), dissolved oxigen is needed to support aquatic organism existence and overhaul of organic materials in the water. Tidal lowland is known to have a high organic matters which if composed by bactery will increase the ammonia production. Ammonia level should not more than $0.002 \mathrm{mg} / \mathrm{L}$ (Effendi, 2003) for fish culture, while in Table 1 the ammonia content in the canals reached $0.24-0.27 \mathrm{mg} / \mathrm{L}$.

Table 1. Water quality Data in the Canals

\begin{tabular}{lcccc}
\hline \multicolumn{1}{c}{$\begin{array}{c}\text { Parameter } \\
\text { Observed }\end{array}$} & \multicolumn{4}{c}{ Range of water quality } \\
\cline { 2 - 5 } & $\begin{array}{c}\text { Primary } \\
\text { Canal }\end{array}$ & $\begin{array}{c}\text { Secondary } \\
\text { Canal }\end{array}$ & $\begin{array}{c}\text { Tertiery } \\
\text { Canal }\end{array}$ & Pond \\
\hline $\begin{array}{l}\text { Temperature } \\
\left({ }^{0} \mathrm{C}\right)\end{array}$ & $28-31$ & $28-31$ & $27-31$ & $27-30$ \\
$\mathrm{pH}$ & $3.0-6.0$ & $3.0-6.0$ & $3.0-6.0$ & $2.0-6.0$ \\
$\begin{array}{l}\text { Disssolved } \\
\text { oxygen (mg/L) }\end{array}$ & $2.0-4.2$ & $2.0-4.2$ & $1.7-4.0$ & $1.9-4.3$ \\
Ammonia & $0.02-$ & $0.02-0.24$ & $0.07-$ & $0.03-$ \\
$(\mathrm{mg} / \mathrm{L})$ & 0.24 & & 0.27 & 0.27 \\
\hline
\end{tabular}


Based on observation results of water source, it is necessary to solve the water quality problem in tidal lolwland with another method. Organic liquid fertilizer is expected to be adequate to manage water quality and provide the live feed to support the fish culture in the reclaimed tidal lowland ponds. It is becaused organic liquid fertilizer contains of many nutrients both macro and micro nutrients. In this research, the previous range of $\mathrm{pH}$ on the ponds were 3.0 to 4.0 , then after liming $\mathrm{pH}$ increased to be 6.8. However, the $\mathrm{pH}$ in ponds declined gradually, accept when the organic liquid fertilizer had applied (P1 and $\mathrm{P} 2$ ), the $\mathrm{pH}$ range kept on tolarance condition and remained more than 6.5 (Figure 2).

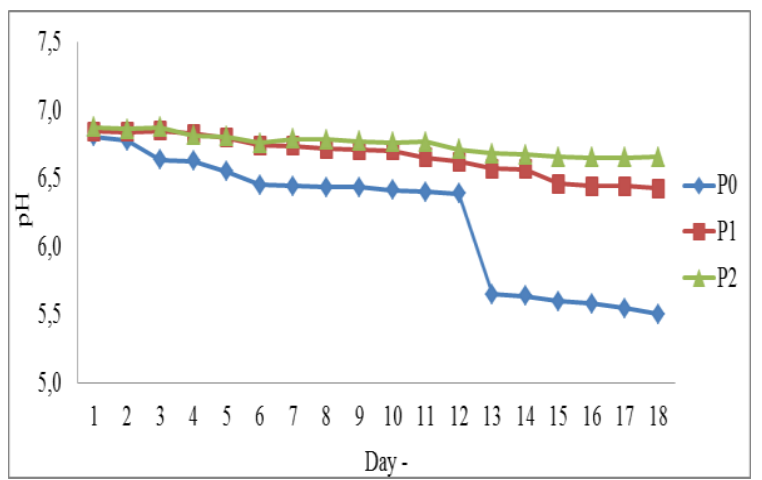

Figure 2. $\mathrm{pH}$ graph on each treatment

The increasing $\mathrm{pH}$ on the pond both with or without addition organic liquid fertilizer are expected becaused there was impact of acidity contained on the land. According to Harsono (2008), reclaimed tidal lowland contains of the high of pyrite. Pyrite oxidation will produce $\mathrm{FeSO}_{4}$ and $\mathrm{H}_{2} \mathrm{SO}_{4}$ in the begining, then $\mathrm{Fe}_{2}\left(\mathrm{SO}_{4}\right)_{3}$ that will be hydrolized so obtains ferrisulphate and Sulfur acid that the reaction is very acid. The addition of organic liquid fertilizer is suspected give good effect for the acid concentration in the pond. Nevertheles on $\mathrm{P} 1$ and $\mathrm{P} 2$, the $\mathrm{pH}$ are also decline, however the decresing is not sharply and it is still could support the fish rearing.

The value of dissolved oxigen and ammonia in all ponds tend to decrease (Figure 3 and 4). The addition of organic liquid fertilizer influent the dissolved oxygen in the pond. The data shows that, eventhough dissolved oxigen in all the ponds declined, the dissolved oxygen in $\mathrm{P} 2$ is the lowest $(1.9 \mathrm{mg} / \mathrm{L})$. It is followed by P1 and $\mathrm{P} 0$ where the dissolved oxigen ranged 2.5$2.7 \mathrm{mg} / \mathrm{L}$. Dissolve oxigen on P1 and P2 ponds drops sharply and become unstable since the second day, means that after treatment was given. These are expected that after fertilizer was put in the ponds, some of bactery will transform the organic and inorganic matters to be another material that can be use by organisms as their nutrients. In this process, the bactery will need many oxigen, thus dissolved oxigen level wil go down. According to Siboro et al. (2013), liquid organic fertilizer also has bactery with a role on the decomposition of organic materials in the water. During the process, the bacteria use the oxigen in the water which will reduce the oxigen level.

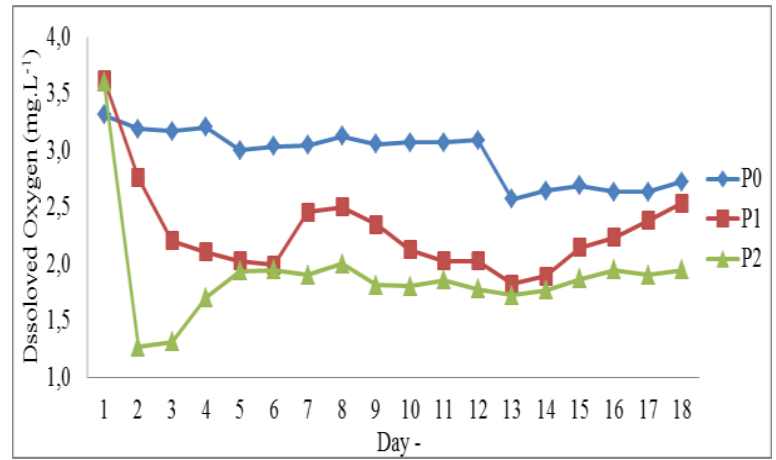

Figure 3. Dissolve oxigen graph on each treatment

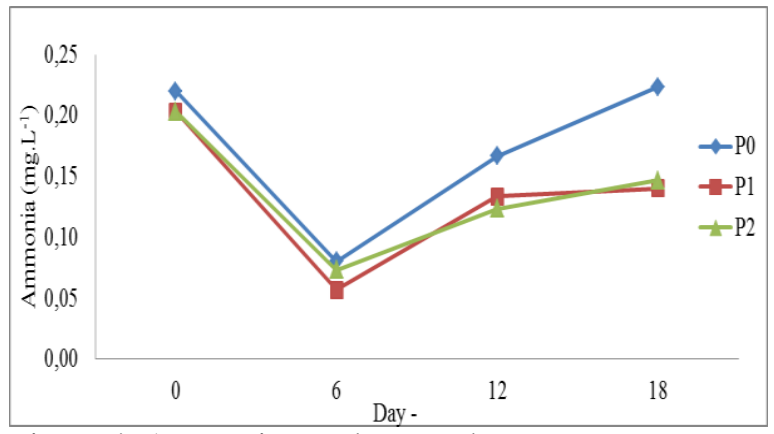

Figure 4. Ammonia graph on each treatment

The data shows that there is an increasing ammonia since dropped in the day- 6 and reach the peak in the last day $(0.15 \mathrm{mg} / \mathrm{L})$ (Figure 4$)$. The suppposition is, the addition of fertilizer affect the organic material in the pond. Macro and micro nutrient levels will increase and make the ammonia high as well. According to Boyd and Tucker (2014), Nitrogen in aquaculture system is intentionally added as fertilizer to enhance primary productivity, however ammonia is quickly liberated when those organic material decomposed.

Based on observation and identification of phytoplankton (Figure $5^{\mathrm{a}}, 5^{\mathrm{b}}$ and $5^{\mathrm{c}}$ ) and zooplankton (Figure $6^{\mathrm{a}}, 6^{\mathrm{b}}$ and $6^{\mathrm{c}}$ ), it was noted that the number of both fitoplankton and zooplankton on P1 and P2 increase since day-3 and reach the peak on day-12 yet it was getting down on day-15. While the number of plankton on control ponds declined in day-3 and increased 
again in day-6 until reached the peak in day 12 . It is suspected that, because the fertilizer is liquid so it is easily soluble in the water. Therefore on day-3 the number of plankton has increased gradually. The plankton (both phytoplankton and zooplankton) amount in P0 were very low, it ranges $57-204 \mathrm{ind} / \mathrm{L}$ and $18-33 \mathrm{ind} / \mathrm{L}$. While in $\mathrm{P} 1$ and $\mathrm{P} 2$ the phytoplankton range were medium, 24-3757 ind/L (P1) and 47-12033 ind/L (P2). Although the zooplankton abundance was low 14-364 ind/L (P1) and 37-419 ind/L (P2). According to Susanti (2010), the amount of plankton will be high if the abundance is more than $1,000,000 \mathrm{ind} / \mathrm{L}$, medium is about 1,000 $1,000,000 \mathrm{ind} / \mathrm{L}$, and it will low if the value is lower than $1,000 \mathrm{ind} / \mathrm{L}$. The increasing of phyplankton amount was suspected because plankton could utilize the nutrient in the pond. Based on Yuliana (2007), the high level of phytoplankton is becaused of the availability of nutrient and space. These is similar as Barus et al. (2013), the amount of nutrient will impact an increasing of phytoplankton amount, thus it could adequate to grow and reproduce well.

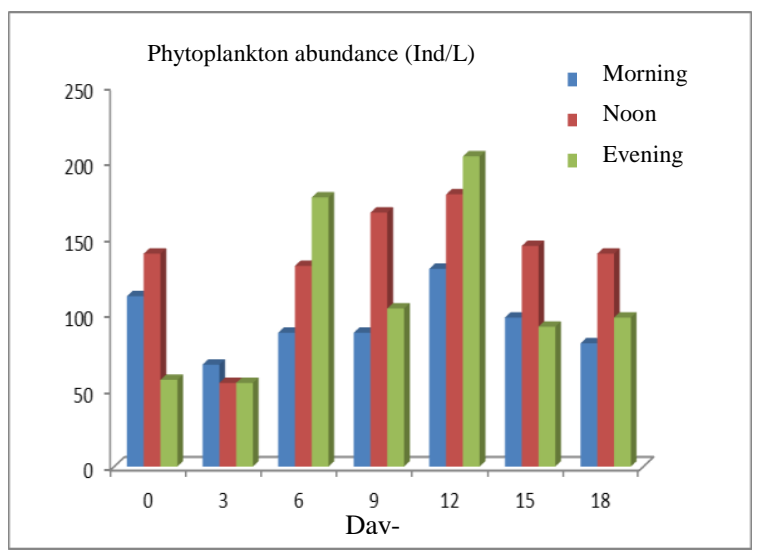

Figure $5^{\text {a }}$. Phytoplankton abundance on P0

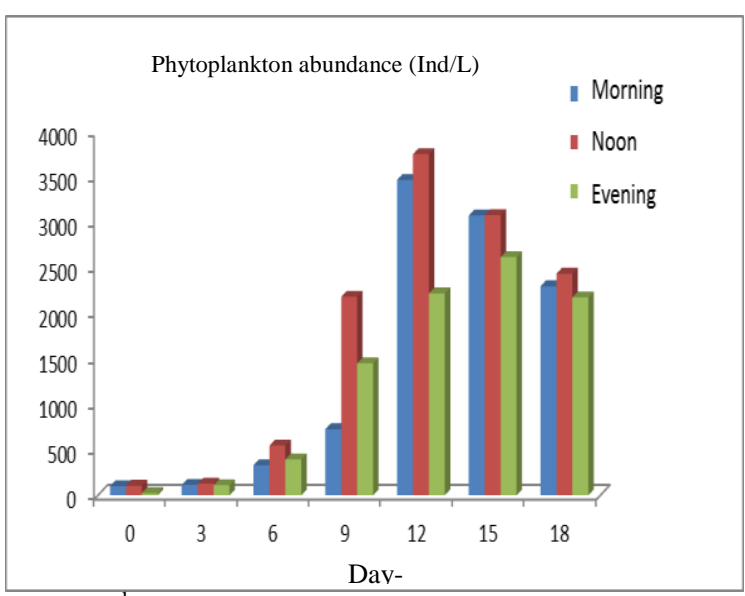

Figure $5^{\mathrm{b}}$. Phytoplankton abundance on P1

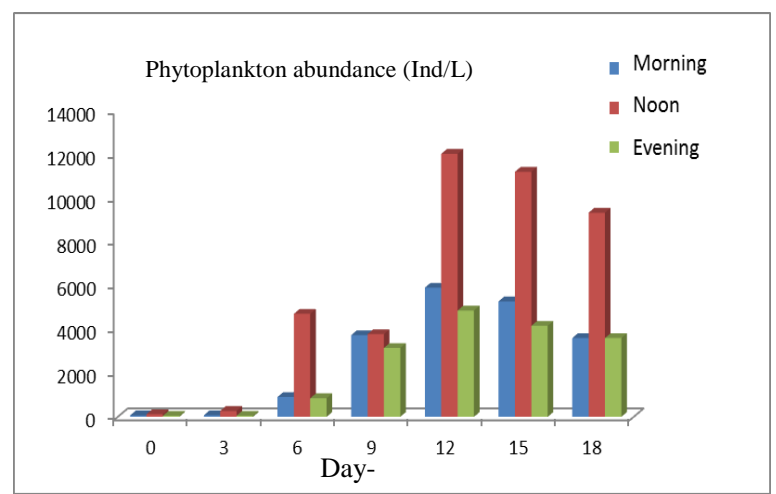

Figure $5^{\mathrm{c}}$. Phytoplankton abundance on P2

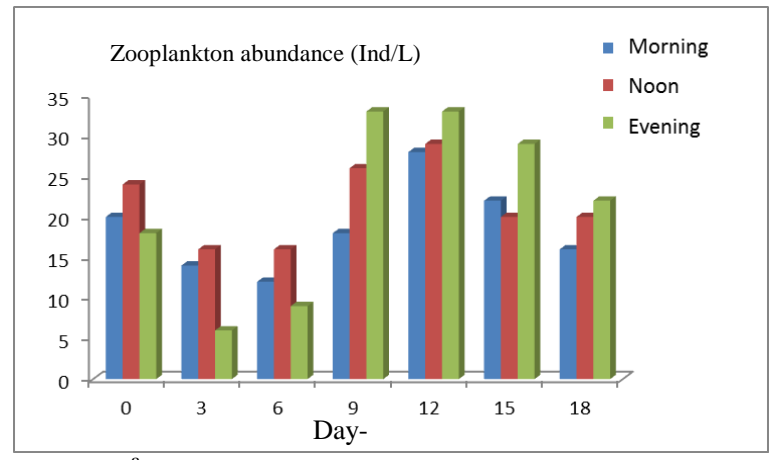

Figure $6^{\mathrm{a}}$. Zooplankton abundance on P0

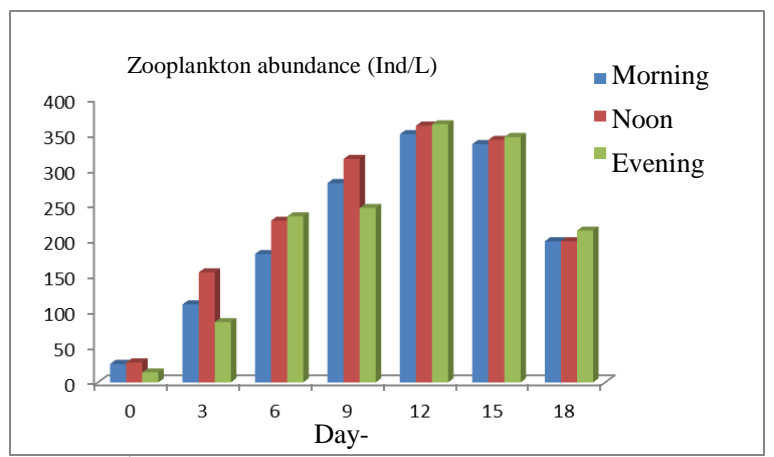

Figure $6^{\mathrm{b}}$. Zooplankton abundance on P1

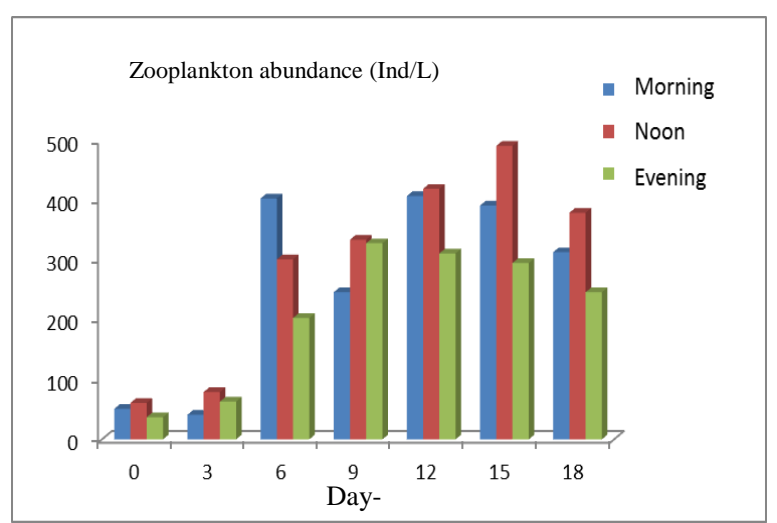

Figure $6^{\mathrm{c}}$. Zooplanton abundance on P2

The variety of fitoplankton that were found in the pond namely; Tabelaria fenestrata, Hapalosiphon hibernicus, Oscillatoria splendida, Asterionella sp., Spirogyra pseudocylindrica, Oedocladium operculatum, Scytonema ocellatum, 
Closterium gracille, Lyngbya limnetica, Aulacantha spinosa, Phormidium mucicola, Fragilaria capucina, Phacus pleuronectes, Stephanodiscus sp., Nitzchia palea, Cyanidium caldarium, Selanastrum minutum, Karatella cochlearis, Bacillaria paradoxa, Phormidium tenue. While zooplankton were Nauplius spp., microcyclops varicans, corethra sp., Anaplectus grnulosus, Heleopera rosela, polyarthra sp., Eurytemora hirundoies, cyanidium caldarium.

\section{Acknowledgement}

We would like to thanks to KEMENRISTEK DIKTI and Sriwijaya University that had funded this study and also to the people who help us doing this research (Ibu Unus, Raudhatus Sa'adah, Fauziyah, Tiararan Kurnia, Yenni Mulyani, Een Karmenda and Eni Sartika).

\section{References}

APHA. 1989. Standard Methods for the Examination of Water AND Wastewater. 17th edition. Washington D.C. 3464 pp.

Barus, S.L., Yusnafi, and A. Suryanti. 2013. Diversity and abundance of periphyton in Deli Rive of South Sumatera. Environtment Jounal, (3) 4: 139-149.

Boyd, C.E. and C.S. Tucker. 2014. Handbook for Aquaculture Water Quality. Craftmaster Printers, Inc., Auburn Alabama. 439 p.

Davis, C.C. 1955. The Marine and Fresh Water Plankton. Michiganstate university Press.

Edmondson, W.T. 1959. Rotifera. Pp. 420-494. In: Fresh-water Biology, 2nd ed. (ed. W.T. Edmondson). John Wiley \& Sons, Inc., NY

Effendi, H. 2003. Study of Water Quality for Management and Water Environtment. Kanasius Publishing Yogyakarta.

Fitrani, M. 2013. Potency of transmigrator yard utilization at reclaimed tidal lowland for fish culture. National Seminar Prociding VII Masyarakat Konservasi Tanah Indonesia (MKTI). Palembang. 229-234 pp.

Fitrani, M., R.H. Susanto, and Marsi. 2014. Water quality management on fish culture pond at reclaimed tidal lowlands. International Seminar Fisheries and Marine Proceeding. Riau University. Pekanbaru.
Haryadi, S., I.N.N. Suryadiputra, and B. Widigdo. 1992. Limnology. Water Quality Method. (Un-published).. Fisheries and Marine Science Faculty of Bogor Agriculture Institute. Bogor.

Harsono, B. 2008. Association of Indonesian agrarian low legal regulation of land. Djambatan, Jakarta.

Marsi, R.H. Susanto, and M. Fitrani. 2014. Hidrology engineering of dig pond in reclaimed lowland yard for tidal aquaculture. National Seminar Prociding. INACID. Palembang.

Mizuno, T. 1979. Illustration of Freshwater Plankton of Japan. Hoikusha Publishing COJLTD. Japan.

Priatmadi, B.J. and A. Haris. 2009. Acidity reaction pyrite compound on the tidal lowland. $J$. TanahTrop., 14(1):19-24. ISSN 0852-257X.

Salam, A. 2010. Water Quality Analysis of Situ Bungur Ciputat Based on Diversity Phytoplankton Index. Science and Tecnology Faculty of UIN Syarif Hidayatullah, Jakarta. (Unpublished paper).

Sedana, I.P., N.A Pamukas, and S. Hasibuan. 2004. Water Quality Management. Riau University. Pekanbaru.

Siboro, E.S., E. Surya, and N. Herlina. 2013. Organic Fertilizer and Biogas Production by Vegetable waste mixture. Chemical Engineering Journal, 2 (3).

Suriadikarta, D.A. 2005. Sulphate acid land management for ariculture. J. Litbang Pertanian, 24:36-45.

Susanti, M. 2010. Abundance and Distribution of Plankton in Waduk Kedungombo. Mathemetics and Science Faculty of Universitas Negeri Semarang. Semarang. (Unpublished paper).

Susanto, R.H. 2010. Lowland Management Strategies for Sustainable Agriculture Development. Soil Program. Sriwijaya University, Indralaya.

Suwanda, S.D.V., Marsi, M. Fitrani, and R.H. Susanto. 2016. Leaching method study with different frequency on Tilapia culture pond $t$ reclimed tial lowland. National Seminar Prociding of Environtment Scence Programe. Riau University. $650 \mathrm{pp}$.

Yuliana. 2007. Stucture and abundance of Phytoplankton and its relation with physic and chemical water in Laguna lake, Ternate, North Maluku. J. Protein, 14 (1) : 85-92. 